\title{
RECONSIDERING PARTICIPATION FOR LOCAL COMMUNITY WELL-BEING IN ECOTOURISM IN GHANA
}

\author{
Gabriel ESHUN* \\ Tourism Programme, KNUST, P.M.B. Kumasi, A/R. Ghana, University of Johannesburg, \\ School of Tourism and Hospitality, South Africa; e-mail: gabriel_eshun_knust@yahoo.co.uk.
}

Tembi M. TICHAAWA

University of Johannesburg, School of Tourism and Hospitality, South Africa, College of Business and Economics, e-mail: tembit@uj.ac.za

\begin{abstract}
Citation: Eshun, G., \& Tichaawa, T.M., (2019). RECONSIDERING PARTICIPATION FOR LOCAL COMMUNITY WELL-BEING IN ECOTOURISM IN GHANA. GeoJournal of Tourism and Geosites, 27(4), 1184-1200. https://doi.org/10.30892/gtg.27406-425
\end{abstract}

\begin{abstract}
This study focused on enhancing participation in ecotourism development for local community well-being. A mixed methodological approach was employed in the data collection and analysis. Semi-structured questionnaires were used to target 327 locals. In addition, in-depth interviews were conducted with relevant key informants. The study revealed that the community was not boosted by any tangible infrastructure as a result of the development of ecotourism based on the Sanctuary. The study further revealed that the majority of the local members had relatively little education and entrepreneurial training to enable them to benefit from ecotourism business. The study recommends improved engagement between the locals and the management to enhance their involvement in the Sanctuary's sustainability. Additionally, the members of the local community should be engaged in entrepreneurial capacity-building programmes to introduce them to tourism and alternative livelihood options towards enhancing their well-being.
\end{abstract}

Key words: ecotourism, sustainability, local well-being, community participation, Ghana

\section{INTRODUCTION}

The World Travel and Tourism Council (WTTC), which represents the global private sector of travel and tourism, estimates that travel and tourism in 2018 contributed $\$ 8.8$ trillion to the global economy. The industry grew faster than did the global economy for the eighth successive year (3.9\% for travel and tourism versus $3.2 \%$ for the global GDP). It also generated $10.4 \%$ of all global economic activity and contributed $10.0 \%$ that is 319 million jobs globally (WTTC, 2019). Consequently, in view of its socio-economic implications, many countries desire to expand their tourism and hospitality industry. However, the literature attests that tourism activities have the potential to disrupt, disturb and damage natural habitats, as well as to erode the socio-economic viability of

\footnotetext{
* Corresponding author
} 
the local communities (Carter et al., 2015). Especially in the rural areas, tourism development can trigger a cascade of social, ecological, cultural, and economic changes that are not easily manageable by the local residents (Rogerson \& Visser, 2004).

Such changes have led to advocacy for a more culturally and environmentally friendly form of tourism (Fennell, 2014; Lawton \& Weaver, 2015; Kimbu \& Tichaawa, 2018; Yasu et al., 2018). In recent years, the above has increased the amount of attention paid to tourism, which has led to the emergence of sustainable forms of tourism with a 'green' objective - to help preserve an ecosystem that also serves as a destination for tourists (Kiss, 2004; Honey, 2008). Broadly known as 'ecotourism', many forms of the above have flourished globally (Scheyvens \& Momsen, 2008; Lawton \& Weaver, 2015). For instance, Nicaragua has positioned ecotourism as an integral part of its economy, and, since 2001, the sector has overtaken coffee, meat and other traditional product exports in terms of economic performance (Zapata et al., 2011). Countries like Kenya, South Africa, Costa Rica and Ecuador have, in addition, positioned themselves as leading ecotourism destinations (Akama et al., 2011; Eshun et al., 2016).

The International Ecotourism Society (2005) defines ecotourism as "responsible travel to natural areas, which conserves the environment and sustains the well-being of the local people". Overtly clear in the definition are the two key tenets of the concept, namely biodiversity conservation and local well-being. Ecotourism promotes what Brechin et al. (2002, p. 53) refer to as the "pragmatic middle ground", namely the mandate for concurrent achievement of biodiversity conservation and community wellbeing. As a consequence of the above, a distinguishing premise of ecotourism is the facilitation and support that it receives from a dense network of local elites, governmental and quasi-governmental agencies, and Non-Governmental Organisations (NGOs) towards achieving what Eshun (2014) refers to as a 'dual mandate', namely the concurrent objective to achieve biodiversity conservation and local well-being. However, the research that has been conducted into ecotourism since the 1980s has been overly silent on positioning well-being as a concept requiring direct exploration and critique (Kiss, 2004; Eshun, 2011; Eshun \& Tonto, 2014; Eshun et al., 2015).

The lack of direct reference to such a cardinal tenet of ecotourism demands that research into ecotourism contribute to addressing the overt lacuna. Eshun et al. (2015) revealed, through their research conducted into the Owabi Wildlife Sanctuary in Ghana, that ecotourism at the site is excessively concerned with biodiversity conservation, at the expense of local well-being. Although Ghana is not the market leader in ecotourism in Africa, the country ranks among the top 25\% of African countries with the greatest diversity of wildlife (Eshun, 2011). In 1992, the country endorsed the Convention on Biodiversity, and, through Legislative Instrument 282, established 15 wildlife protected areas, which currently cover 38 ooo $\mathrm{km}^{2}$, being $16 \%$ of the country's land area, while, outside the protected areas, an estimated $4000 \mathrm{~km}^{2}$ of forests still exist (Eshun \& TagoeDarko, 2015). Currently, three types of ecotourism development exist in Ghana, namely state-led ecotourism, community-based ecotourism and privately-owned ecotourism (Eshun, 2011, 2014). Kiss (2004) states that 32 out of the 55 World Bank-financed projects that supported conservation efforts in Africa between 1988 and 2003 included community-based ecotourism. However, a cursory observation of the ecotourism scholarship landscape in Africa shows that the state-led ecotourism sites continue to receive more research attention, at the expense of lesser known ecotourism attractions (Attuquayefio \& Gyampoh, 2010; Eshun, 2011). Some popular examples ecotourism projects in Africa include the Communal Areas Management Programme for Indigenous Resources (CAMPFIRE) in Zimbabwe; the Okavango Delta CBNRM project in Botswana; the Makuleke Contract Reserve in South Africa; the Luangwa Integrated Rural 
Development Project and the Administrative Management Design (ADMADE) for game management areas, both in Zambia; the Living in a Finite Environment programme in Namibia; the Tchuma Tchato 'Our Wealth' in Mozambique; the Conservation of Biodiversity Resource Areas programme (COBRA) in Kenya; and the Ujirani Mwena 'Good Neighbourliness' programme in Tanzania (Honey, 2008; Akama et al., 2011; Mensah \& Adofo, 2013; Eshun, 2014). Consequently, the current study aims to depict how the Kubease community benefits from the Bobiri Forest Reserve and Butterfly Sanctuary (BFRBS) in Ghana, through their participation in ecotourism. The study sought to achieve the above by focusing on the different effective ways in which the local people have been, and can continue to, participate in ecotourism development towards their own well-being.

\section{LITERATURE REVIEW}

According to Coria and Calfucura (2012), ecotourism is often located in destinations that are marginalised and that are characterised by a lack of monetary resources, local skills and mechanisms to ensure the fair distribution of benefits, in addition to their poor commercial links and their relative inexperience in planning, finance and product development. Increasingly, the research currency has improved in relation to community issues to do with ecotourism (Hellmann, 2011; Eshun \& Tonto, 2014; Dumbe et al., 2018). Eshun (2014) argues that the concept of 'community' in ecotourism is, therefore, still overtly tenuous in terms of concept, with it being tortuous in practice. Such a situation fosters debate on the use of the term 'local residents' as against the term 'community', since the former term positions discourses on stakeholders as including all the individuals residing around eco-destinations, regardless of whether or not they are natives of the area. Eshun et al. (2015, p. 4) define community well-being as consisting of "the totality of efforts towards social resilience of local residents around ecotourism destinations through minimal external control and provision of alternative livelihood strategies”. Additionally, in terms of the triple bottom line concept of ecotourism, the sense of community wellbeing results from the economic and sociocultural impacts of such tourism (Honey, 2008; Fennell, 2014). Although many authors do not define the idea of community well-being in terms of their tourism scholarship, many position participation as being the most central tenet under the all-embracing term, which, alongside biodiversity conservation, contributes towards the achieving of sustainable development (Chan \& Bhatta, 2003; Scheyvens \& Momsen, 2008). Nkemngu (2015) argues that issues of community well-being fall under the ambit of the social exchange theory, which posits that people, or communities, tend to trade their support for projects in exchange for the benefits that they stand to gain, for example from ecotourism development. Sustained global attention has been paid to participation in ecotourism development and sustainability (Simpson, 2008; Hellmann, 2011; Zapata et al., 2011; Eshun \& Tonto, 2014; Zinda et al., 2014; Schmidt \& Uriely, 2018). Indeed, a copious amount of research posits trenchantly the need for sustained research into participation in ecotourism in Africa, towards addressing the development needs of the local communities (Akama et al., 2011; Mensah \& Adofo, 2013; Harilal \& Tichaawa, 2018). Community participation has become a cardinal consideration in terms of ecotourism development (Tosun, 2000; Ramón-Hidalgo et al., 2018).

The concept has been invariably defined as implying how, and to what extent, the locals are able to share their views, participate in an activity, make decisions, and share profits, as well as perform other actions related to the tourism development process (Kiss, 2004; Attuquayefio \& Gyampoh, 2010). Community participation is important to accomplishing successful ecotourism development, because communities should take the lead in natural resource management, since they often bear the brunt of resource utilisation (Akama et al., 2011; Eshun, 2011). For instance, with regard to the CAMPFIRE 
projects conducted around Mahenye and Chipise in Zimbabwe, the local communities maintain that the financial rewards that are generated from the projects are insufficient to compensate for the costs exacted in the form of crop and livestock raiding by the wildlife and in the form of the prohibitions that are imposed on such use of the natural resources as hunting, fishing and pole collection (Chuitsi et al., 2011; Tichaawa \& Mhlanga, 2015). The local stakeholders at the ecotourism destinations include mainly the residents, the local business owners, the local unions and the local non-governmental organisations. The stakeholders, who have both similar and divergent interests, are expected to participate in the tourism trade, as well as in the planning and decision-making for successful ecotourism development (Lacher \& Nepal, 2010).

A myriad reasons are presented by the proponents of participatory governance in relation to ecotourism development. Increasingly, the involvement of the locals in decision-making is seen as a means of: accommodating community-relevant values and interests; protecting and promoting cultural diversity and human rights; and promoting viable solutions that balance conservation and competing pressures arising from socioeconomic development (Tosun, 2000; Honey, 2008; Buckley, 2009; Ramón-Hidalgo et al., 2018). The local communities expect to gain both direct and indirect economic benefits from the ecotourism development that occurs around the protected areas (Akama et al., 2011; Eshun, 2011; Eshun \& Tagoe-Darko, 2015; Dumbe et al., 2018). Considering that community aspirations and involvement are cardinal considerations for sustainable ecotourism development (Eshun \& Tonto, 2014), community participation in ecotourism can lead to the development of such facilities as roads, parks, recreational activities and cultural attractions; also, community participation increases the environmental awareness of other people (Rogerson \& Visser, 2004; Scheyvens \& Momsen, 2008; Simpson, 2008; Shehab, 2011; Amoah \& Wiafe, 2012). Local communities know the nature and characteristics of their ecotourism products more intimately than do any outsiders, as the related products and activities are frequently associated with the maintenance of traditions, the holding of local ecological knowledge, and the encouragement of cultural values (Dumbe et al., 2018; Yasu et al., 2018).

Local communities, which are key stakeholders in every aspect of ecotourism development, are crucial to the success of sustainable ecotourism development (Buckley, 2009). To address the marginalisation of the local communities, the need exists to involve them in the planning and decision-making process regarding the management and future development of ecotourism in their areas (Fennell, 2014). Also, the premise has been mooted that local involvement enhances the sustainability of ecotourism (Hellmann, 2011; Boley \& McGehee, 2014). The benefits received by the local community motivate them to participate in ecotourism, in the capacity of, for example, local guides, homestay hosts, and the sellers of local products and services (Amoah \& Wiafe, 2012; Zinda et al., 2014).

Tosun (2000) classifies local participation into three types: spontaneous; coercive; and induced. Spontaneous participation represents the perfect mode of local participation, as it imbues the host community with full managerial authority. Thus, such participation corresponds to citizen power in terms of Arnstein's typology. Induced participation lessens the full involvement of the local people, despite them still being allowed to have their say in tourism development, with it seeking to reduce the number of socio-political risks that are associated with tourism development. For instance, Belsky (1999) points out that, at Gales Point Manatee, Belize, the views of the locals were misrepresented to suit the plans of the developers. Coercive participation, which is top-down, has a higher propensity to reduce the concomitant benefits for the locals (Eshun \& Tonto, 2014). In such a case, the extra-powerful actors, like the governmental and quasi-governmental agencies, the multinational corporations, and 
the worldwide tour operators, make the necessary decisions regarding, and manage, the ecotourism involved (Honey, 2008). Discourses on participation still remain sparse as to how the locals can actually become the managers of resources in their own domains (Eshun, 2011). The increasing ascendency of community-based ecotourism is one such move that has been made towards the locals achieving spontaneous participation (Kiss, 2004). The milieu of community-based ecotourism encompasses the mandate to empower the local people and to improve their standard of living, such as through increasing their amount of disposable income (Eshun, 2014; Eshun \& Tagoe-Darko, 2015; Ilies et al., 2017). Besides the economic benefit of ecotourism, is the psychological empowerment of the local people through ecotourism, which is cardinal in enhancing the locals' sense of self-esteem, and in cultivating their sense of pride in relation to their cultural and natural heritage (Honey, 2008; Mbaiwa, 2008; Ramón-Hidalgo et al., 2018; Schmidt \& Uriely, 2018). Eshun et al. (2015) caution that the local communities must not naïvely embrace ecotourism as a panacea for all their ills, since other competing interests might result in few benefits accruing to themselves. The above, therefore, fosters debate on how issues of community participation should move beyond the indigenousness of residents toward teasing out the mosaic of power underpinning the global, national and local dynamics of ecotourism development (Figure 1).

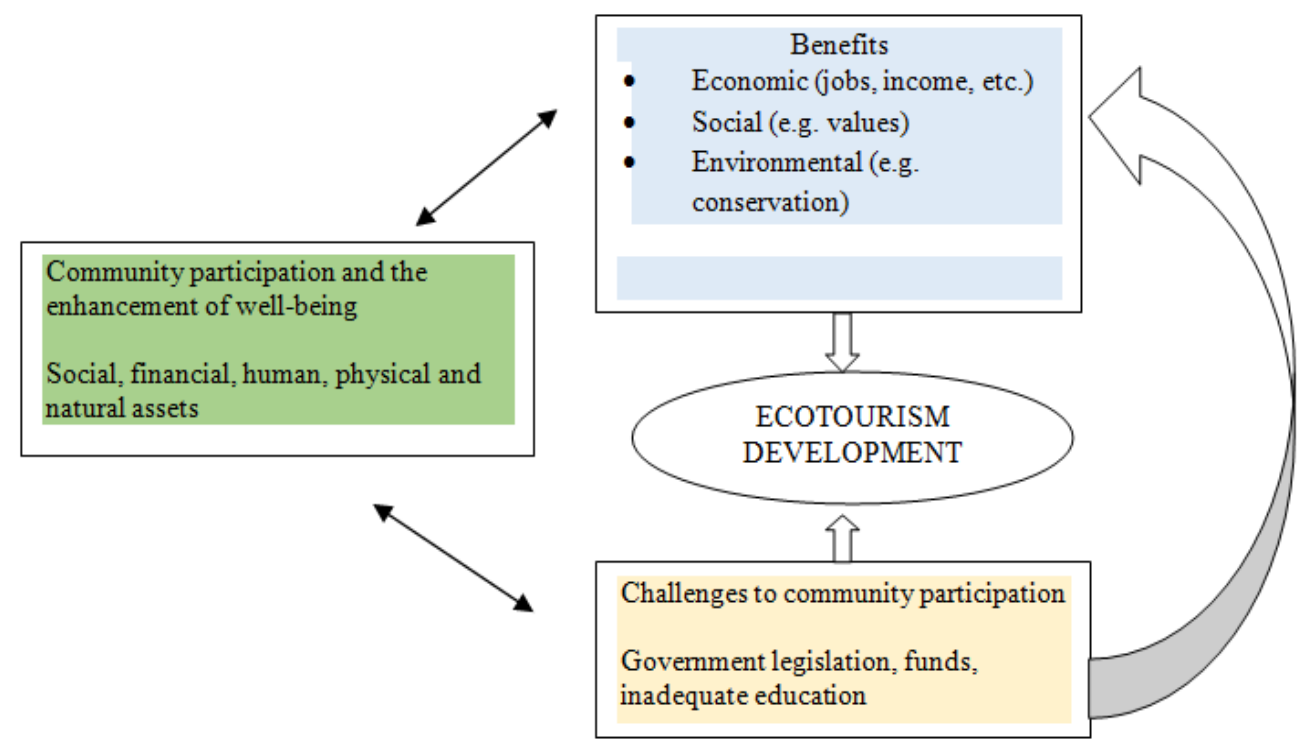

Figure 1. The nexus of ecotourism and participation

Carter et al. (2015) also argue cogently that popular participation in tourism can be used by the existing power structures as a hegemonic device for securing control. Many authors posit local participation in ecotourism as serving as a motivating force behind the locals becoming engaged in ecotourism activities (Kiss, 2004). The motivation of the locals varies from encouraging them to engage in the selling of crafts, to gain direct employment, to interact with the visitors, and to project the image of their communities through tourism development (Rogerson \& Visser, 2004; Eshun \& Tagoe-Darko, 2015).

Thus, local participatory challenges in ecotourism continue to receive research attention, since they tend to derail its sustainability (Ashley \& Jones, 2001; Amoah \& Wiafe, 2012; Eshun \& Tonto, 2014). Such challenges limit the locals' participation, so 
that they are not able to maximise the full potential of the ecotourism activities occurring in their community (Akama et al., 2011).

\section{MATERIALS AND METHODS}

The BFRBS was created in 1939, when it was still an unexploited primary forest. The Sanctuary, which falls within the tropical moist semi-deciduous Forest Zone, lies between latitudes. The complex was awarded for being an outstanding Tourist Support in 1999, and for being the Tourists Attraction of the Year in 2001, by the Regional Tourist Board (Eshun et al., 2016). The total area of the Reserve is $54.6 \mathrm{~km}^{2}$ in diameter. Named after the river that passes through the middle of the Reserve, it was created as a result of the increased demand for logs during World War II. The Reserve, which is endowed with a variety of flora and fauna, also supports a rich array of fauna, with the most prolific being butterflies and birds. About 400 butterfly species have been recorded in the Reserve, as well as Mona, white-nosed, green, and black-and-white monkeys (Eshun et al., 2016). The Reserve hosts the Bobiri Forest Arboretum, with about 100 indigenous species on 1.7ha of land (see a map of the Sanctuary in Figure 2). The Sanctuary contains 340 butterfly species and about 120 bird species (Dumbe et al., 2018).

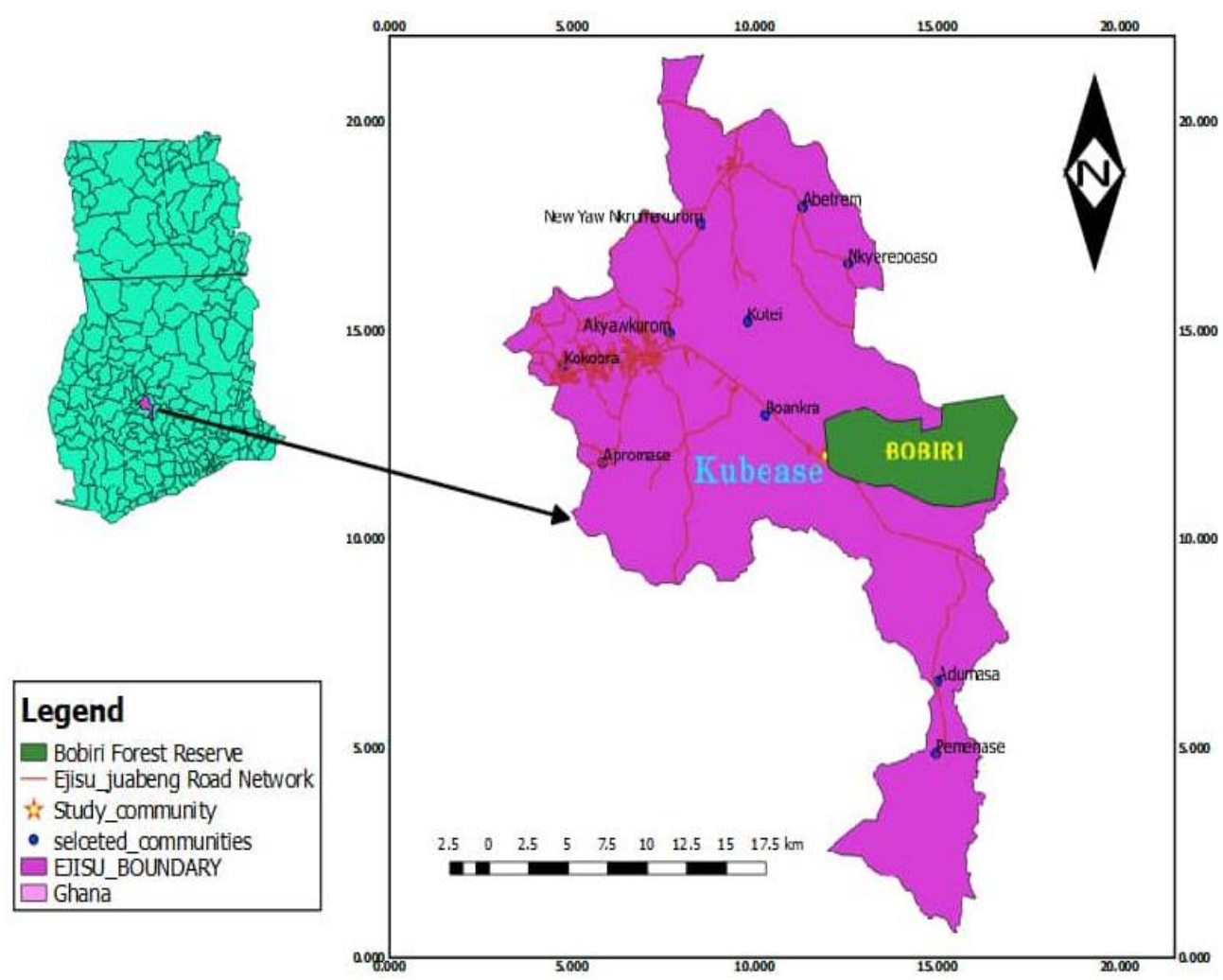

Figure 2. Map of the BFRBS, showing the study area concerned (Source: Ghana open data)

In terms of the rarity of faunal species and its unique selling proposition, the Sanctuary is the only butterfly sanctuary in West Africa, with it boasting of, arguably, one of the biggest butterfly species in West Africa (Papilio antimachus), as well as of the reed frog (Hyperolius bobirensis). The reed frog, which is endemic to the site, is listed on the 
IUCN Red List of threatened species (Wagner et al., 2008). The appeal of ecotourism is predominantly based on how it markets the rarity and richness of faunal and floral species at destinations (Honey, 2008; Eshun, 2014; Fennell, 2014). Also, other ecotourism services at the Sanctuary include: adventure travel; outdoor recreational activities; and educational tours, including a chance to discover new cultures and locations, and promotion of the desire to undertake epistemological studies on nature.

The Reserve, which is administered by the Forest Research Institute of Ghana, has been identified as being the largest preserved parcel of land, with lush greenery and a mystifying atmosphere. It is one of the most beautiful and magnificent forest reserves in West Africa, harbouring tall and imposing ancient trees. Ecologically, the Bobiri Forest Reserve falls within the tropical moist semi-deciduous forest zone, with it having an annual mean rainfall of between $1200 \mathrm{~mm}$ and $1750 \mathrm{~mm}$. The annual temperature ranges between $20^{\circ} \mathrm{C}$ (August) and $32^{\circ} \mathrm{C}$ (March). The distribution of rainfall patterns and temperature enhances the growth of flora and fauna in the area. The Bobiri Forest Reserve hosts the Bobiri Arboretum and the Butterfly Sanctuary (Eshun et al., 2016).

In terms of the tourist market, the Sanctuary is located 20km from the Kumasi and Accra highway and 3okm from Kumasi, which increases its accessibility. The study employed a mixture of both quantitative and qualitative methods to collect the required data for addressing the objectives of the study. Applied researchers in tourism have encouraged adopting mixed-method approaches, combining ethnographic with quantitative methodologies, to reach an understanding of current tourism-related challenges and to facilitate the undertaking of collaborative, culturally sensitive research (Ramón-Hidalgo et al., 2018). Questionnaire and interview guides were the data collection instruments. The research, which used cross-sectional design, included the collection of data from more than one case and at a single time, through the use of semistructured questionnaires and interviews. The purposive sampling method was used in selecting Kubease as the study community, because of its closeness to the Sanctuary.

The study used the simple random sampling method in selecting the required respondents from the community. To help provide in-depth data on the study objectives, the study also purposively selected and interviewed the management of the Sanctuary, including four of its workers, and five opinion leaders from the Kubease community. The quantitative data were analysed using descriptive and inferential statistics, whereas the qualitative data were analysed using thematic analysis.

\section{RESULTS DISCUSSIONS}

\section{Sociodemographic characteristics of the respondents}

The current section is intended to describe the demographic variables of the sample, so as to achieve the objective of the study, entailing the reconsideration of the local participation, with the intention of enhancing its well-being. The demographic variables obtained from the participants included their sex, age, educational level, occupation, marital status, monthly income, and length of stay in Kubease.

The percentage of men and women was relatively well-distributed. In all, the proportion of women, however, slightly exceeded (1.6\%) that of the men. The ages of the respondents were categorised into four, with 126 (38.5\%) of the respondents being aged between 18 and 28 years old, with 82 (25.1\%) being aged between 29 and 39 years old, and with 61 (18.7\%) being aged between 40 and 49 years old. The age ranges resembled the national statistics, in terms of which those who were younger than 25 years old were found to form over 50.0\% of the population of Ghana (Ghana Statistical Service, 2012). However, $58(17.7 \%)$ of the respondents were older than 50 years. Considering the level of education of the respondents, 64 (19.6\%) had only an informal education, 168 (51.4\%) 
had a basic education, and 95 (29.0\%) had a secondary education. None of the respondents from the local community had a tertiary education. The above figures could suggest that most of the human capital available in the community are likely to fall in the lower and middle employment categories. Eshun (2011) argues that, generally, the educational level of the communities around the ecotourism sites in Ghana is low, which conforms to that of most rural communities in the country. The existing research outputs confirm that the employment opportunities for the local communities are mainly available at a low level, due to the provision of inadequate education and training (Lacher \& Nepal, 2010; Amoah \& Wiafe, 2012; Eshun, 2014). Similarly, in research about the Okavango Delta in Botswana, the majority of the local residents were found to work in unskilled positions, while expatriates tended to be employed in management positions, earning much more than did the local residents (Mbaiwa, 2008).

Table 1. Sociodemographic characteristics of the respondents (Data source: Fieldwork, 2019)

\begin{tabular}{|c|c|c|c|}
\hline $\begin{array}{c}\text { Sociodemographic } \\
\text { characteristics }\end{array}$ & Variables & Frequency (N) & Percentage (\%) \\
\hline \multirow{3}{*}{ Sex } & Male & 161 & 49.2 \\
\hline & Female & 166 & 50.8 \\
\hline & Total & 327 & 100 \\
\hline \multirow{5}{*}{ Age (in years) } & $18-28$ & 126 & 38.5 \\
\hline & $29-39$ & 82 & 25.1 \\
\hline & $40-49$ & 61 & 18.7 \\
\hline & Over 50 & 58 & 17.7 \\
\hline & Total & 327 & 100 \\
\hline \multirow{5}{*}{ Education } & Informal & 64 & 19.6 \\
\hline & Basic & 168 & 51.6 \\
\hline & Secondary & 95 & 29.0 \\
\hline & Tertiary & 0 & 0 \\
\hline & Total & 327 & 100 \\
\hline \multirow{5}{*}{ Marital status } & Single & 111 & 33.9 \\
\hline & Married & 173 & 52.9 \\
\hline & Divorced & 20 & 6.1 \\
\hline & Widowed & 23 & 7.1 \\
\hline & Total & 327 & 100 \\
\hline \multirow{8}{*}{ Occupation } & Farmer & 72 & 22 \\
\hline & Trader & 145 & 7.1 \\
\hline & Student & 7 & 2.1 \\
\hline & Driver & 36 & 11.1 \\
\hline & Security & 59 & 18.1 \\
\hline & Unemployed & 7 & 2.1 \\
\hline & Teacher & 1 & 0.3 \\
\hline & Total & 327 & 100 \\
\hline \multirow{8}{*}{ Monthly income ( $\varnothing$ ) } & Below 50 & 69 & 21.1 \\
\hline & $50-200$ & 92 & 28.1 \\
\hline & $201-351$ & 50 & 15.3 \\
\hline & $352-501$ & 67 & 20.5 \\
\hline & $502-652$ & 18 & 5.5 \\
\hline & Above 652 & 20 & 6.1 \\
\hline & None & 11 & 3.4 \\
\hline & Total & 327 & 100 \\
\hline
\end{tabular}

Of the total number of respondents, 111 (33.9\%) were single and 173 (52.9\%) were married, whereas 20 (6.1\%) were divorced. However, 23 (7.1\%) were widowed. Considering their occupation, 72 (22\%) were farmers, 145 (44.3\%) were traders, 36 (11.1\%) were drivers, 59 (18.1\%) were security personnel, 7 (2.1\%) were students, and 1 
(0.3\%) was a teacher. However, 7 (2.1\%) of the respondents were unemployed. With trading being the most-often followed occupation, the number of visitors to the Sanctuary and the frequency of sales made at the toll booth in the community had definitely influenced their occupational choice. The shift from farming to trading around the ecotourism sites in Ghana is generally due to globalisation, the reduced amount of available farming land and the low return on subsistence farming produce (Eshun, 2011). Of the total number of respondents, $69(21.1 \%)$ had a monthly income of less than 50 Cedis, with 92 (28.1\%) having a monthly income of between 50 and 200 Cedis.

Of the remainder of the respondents, 50 (15.3\%) had a monthly income of between 201 and 351 Cedis, with 67 (20.5\%) having a monthly income of between 352 and 501 Cedis, with 18 (5.5\%) earning between 502 and 652 Cedis per month, and 20 (6.1\%) having a monthly income of above 652 Cedis. However, 11 (3.4\%) of the respondents received no monthly income at all. The prevailing low-income brackets could have prevented the locals from engaging and investing in tourism.

\section{Limitations of the locals regarding ecotourism development}

In the first place, the locals were asked to state whether there were limitations to engaging in activities in, and around, the Sanctuary. The findings revealed that 87 (26.6\%) of the respondents (i.e. the locals) clearly stated that there were limitations to engaging in activities in, and around, the Sanctuary, whereas 240 (73.4\%) of the respondents stated otherwise. A respondent noted:

"We are limited because of the regulations governing the Sanctuary. Also, we accuse the management of being hegemonic by prohibiting us from entering the forest to retrieve resources, such as cutting trees for pestles, picking snails, collecting mushrooms and herbs, and felling of trees for timber." (Interview, a farmer in Kubease, 2019).

At the time of the current study, the majority of the locals did not participate in ecotourism, due to the centralisation of management. Earlier, Tosun (2000), in relation to induced participation, implied that the locals could be authorised to have a say in tourism development, but that their views were often sidelined by the more powerful actors concerned. The above notwithstanding, some of the community members added that the restrictions helped in protecting the Sanctuary, because allowing every member of the community access to the area and its resources will create 'tragedy of the commons'. Such has been the posture of the Ghanaian government, with the locals' attempts to become key stakeholders in managing the national parks being curtailed, due to the presence of ample evidence of their antithetical behaviour towards biodiversity conservation (Eshun, 2011, 2014; Amoah \& Wiafe, 2012). Tosun (2000) classified the barriers to community participation as falling into three distinct areas, namely operational, structural and cultural limitations. Similarly, toward improving the local participation in the tourism development and management at the Sanctuary, the present study summarised the major limitations under the same three broad categorisations.

Currently, at the cultural level, was the issue of chieftaincy disputes, which was due to the issue of power struggle among the indigenes, which stalled development in the community. Limitations at the operational level consisted of the centralisation of public management, the lack of coordination, and the shortage of information. Structural limitations included: the attitudes of specialists; the lack of information; the elitism; the high level of favouritism and nepotism; the high level of clashes among the supporters of different ideologies or tribes; the lack of trained human resources, particularly the high cost of local participation; and the absence of financial sources. In Bobiri, the management of ecotourism activities was solely in the hands of the FORIG (Table 2). In examining the 
human assets of the respondents, ecotourism at the Sanctuary was found to have contributed little opportunity, so far, to the training and education of the locals. During the emergence of ecotourism in Ghana, several efforts were made to create alternative local livelihood options and environmental education opportunities, but they waned over the years, especially at the government-controlled ecotourism sites (Eshun, 2011).

Table 2. Tosun's concept of community limitation in terms

of evaluating the Kubease community (Data source: Fieldwork)

\begin{tabular}{|l|l|l|}
\hline \multicolumn{1}{|c|}{ Cultural limitation } & \multicolumn{1}{c|}{ Operational limitation } & \multicolumn{1}{c|}{ Structural limitation } \\
\hline 1. Chieftaincy disputes & 1. Lack of requisite skills & $\begin{array}{l}\text { 1. Perception of their irrelevance in } \\
\text { decision-making }\end{array}$ \\
\hline $\begin{array}{l}\text { 2. Low level of ecotourism } \\
\text { awareness in the community }\end{array}$ & $\begin{array}{l}\text { 2. Lack of knowledge in } \\
\text { tourism business }\end{array}$ & 2. Low standard of living \\
\hline 3. Lack of education & $\begin{array}{l}\text { 3. Restrictions from } \\
\text { management }\end{array}$ & $\begin{array}{l}\text { 3. Inadequate welfare services for the } \\
\text { community }\end{array}$ \\
\hline 4. Poor living conditions & 4. Lack of financial resources & 4. Low disposable income \\
\hline 5. Marginalisation of the locals & $\begin{array}{l}\text { 5. Insufficient access to } \\
\text { tourists by the locals }\end{array}$ & 5. High unemployment rate \\
\hline $\begin{array}{l}\text { 6. Different communities with a } \\
\text { stake in the Sanctuary }\end{array}$ & & 6. Cases of favouritism and nepotism \\
\hline & & $\begin{array}{l}\text { 7. Restrictions by the Sanctuary's } \\
\text { management }\end{array}$ \\
\hline
\end{tabular}

\section{Rating local participation in ecotourism development at the Sanctuary}

Regarding the local participation in ecotourism at the Sanctuary, of the 327 respondents, only $3(0.9 \%)$ mentioned that it was very good, with $52(18.0 \%)$ stating that it was good. Of the total number of the respondents, the majority, consisting of 144 (44.0\%) who said that the locals participated averagely in the Sanctuary and 131 (37.0\%) who mentioned that the locals participated poorly in ecotourism at the BFRBS, noted otherwise. The management noted that the locals participated in ecotourism development by selling their wares to tourists at the Sanctuary on holidays and other occasions.

When the locals were asked whether they were involved in decision-making about the Sanctuary, the results revealed that 64 (19.6\%) of the respondents took part in decision-making regarding the Sanctuary (Figure 3). However, as many as 263 (80.4\%) of the respondents indicated otherwise. Earlier research undertaken into ecotourism sites in the developing countries attests similarly to the locals having been relatively little engaged in decision-making and revenue-sharing (Simpson, 2008; Akama et al., 2011; Eshun, 2011; Eshetu, 2014; Eshun, 2014; Eshun \& Tonto, 2014; Nkemngu, 2015; Schmidt \& Uriely, 2018). The current study showed, further, that 91 (27.8\%) of the respondents lacked the requisite knowledge and ideas required for participating in the decisionmaking taking place occurring the Sanctuary. In addition, 44 (6.7\%) of the respondents noted that they were not involved in the decision-making because of the chieftaincy disputes, with 93 (35.4\%) stating that they did not participate in the Sanctuary, because the management saw them as lacking the requisite knowledge. Earlier research revealed that the management often saw the locals as lacking the requisite knowledge to be able to contribute to ecotourism sustainability (Attuquayefio \& Gyampoh, 2010; Mensah \& Adofo, 2013; Eshun et al., 2015). At the time of the current study, most of the locals stated that they felt that the management did not allow them to become involved in decision-making about the Sanctuary, which negatively affected their willingness to participate in research regarding the Sanctuary. Indeed, they claimed that the research that had been undertaken so far had not helped them to become fully involved in the management of the Sanctuary. Eshun and Tonto (2014) show a similar situation to have occurred at the Boabeng-Fiema 
Monkey Sanctuary in Ghana, where the locals demanded gifts from the researchers in exchange for their participation in the research, for similar reasons to the aforementioned.

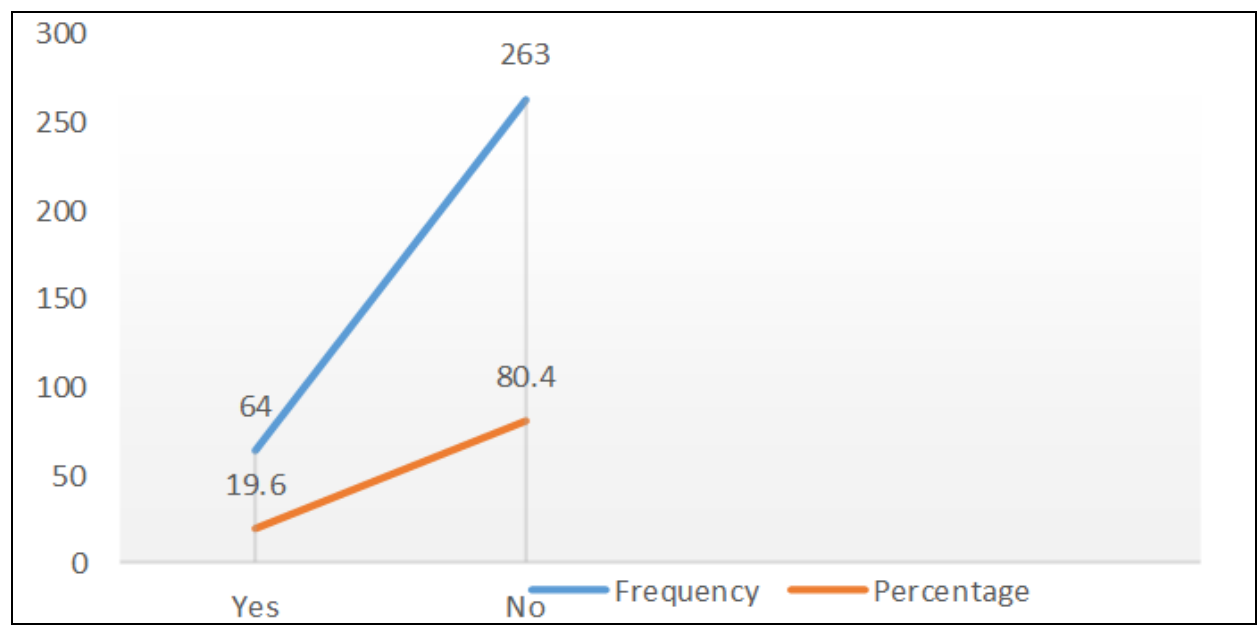

Figure 3. Involvement of the locals in decision-making about the Sanctuary (Source: Fieldwork, 2019)

Increasingly, the proponents of community participation in ecotourism development posit trenchantly that engaging the host communities in ecotourism development and management contributes to effective and equitable benefit-sharing, promotes entrepreneurship (e.g. the sale of handicrafts, and the provision of service at the local restaurants), and generates employment, as well as promoting social cohesion in the communities concerned (Kiss, 2004; Simpson, 2008; Eshun, 2011; Eshetu, 2014; Nkemngu, 2015; Schmidt \& Uriely, 2018).

\section{and training}

Linear regression model of the relationship between decision-making

The relationship between the various stakeholders in the Sanctuary made some of the locals feel irrelevant in terms of the decision-making process.

Table 3. A linear regression model of the relationship between decision-making and training (Data source: Fieldwork)

\begin{tabular}{|l|l|l|l|l|}
\hline Model & $\mathrm{R}$ & R square & Adjusted R square & Std error of the estimate \\
\hline 1 & $.064^{\mathrm{a}}$ & .004 & .001 & .12283 \\
\hline
\end{tabular}

Predictors: (Constant) Involvement in decision-making

Some also stated that they felt that they lacked the needed or requisite knowledge to be involved in effective decision-making. Their involvement in decision-making was used to predict the nature of the training that the locals received from the Sanctuary. Based on the results obtained, no significant value was found between involvement in decision- making and training, with the help of regression, since the $\rho$ value (0.005) is less than the significance value (0.248) in the regression model. Consequently, $0.1 \%$ of the variance in involvement in decision-making is explained by the training of the locals.

Generally, when the locals gain the requisite skills through appropriate training, their upskilling increases their chances of being able to participate in the relevant ecotourism development and management (Ashley \& Jones, 2001; Zinda et al., 2014; Nkemngu, 2015; Schmidt \& Uriely, 2018). In addition, the chi-square value of interaction and education 
is 10.939, at a significance of 0.090 , which depicts the relationship between the interaction with tourists and the educational level of the respondents from the Kubease community. As a consequence, the higher the educational level of a respondent, the greater was their likelihood of interacting with the tourists in the study community.

Table 4. A linear regression model of the relationship

between decision-making and training (Data source: Fieldwork)

ANOVA ${ }^{\mathrm{a}}$

\begin{tabular}{|l|c|c|c|c|c|}
\hline Model & Sum of squares & df & Mean square & F & Sig. \\
\hline Regression & .020 & 1 & .020 & 1.338 & $.248^{\mathrm{b}}$ \\
\hline Residual & 4.903 & 325 & .015 & & \\
\hline Total & 4.924 & 326 & & & \\
\hline
\end{tabular}

a. Dependent variable: Members' training

b. Predictors: (Constant) Involvement in decision-making

Table 5. Chi-square tests showing the relationship between Interactions with Tourists and Education (Data source: Fieldwork)

\begin{tabular}{|l|l|l|l|l|}
\hline Chi-square tests & Value & Df & Asymptotic (two-sided) & Significance \\
\hline Pearson chi-square & $10.939^{\mathrm{a}}$ & 6 & .090 & \\
\hline Likelihood ratio & 10.956 & 6 & .090 & \\
\hline Linear-by-linear association & 3.056 & 1 & .080 & \\
\hline N of valid cases & 326 & & & \\
\hline
\end{tabular}

Five cells (41.7\%) have an expected count less than 5 . The minimum expected count is .03.

The relevant literature on tourism also posits a higher interaction between the tourists and the educated locals than with the relatively uneducated ones (Scheyvens \& Momsen, 2008; Simpson, 2008; Attuquayefio \& Gyampoh, 2010; Eshetu, 2014).

Factors enhancing good interaction between the tourists and the locals

Tourism is, essentially, a service industry, and, thus, issues of the moment of truth are cardinal to the matter of actual and potential visitors to tourist destinations (Kiss, 2004; Rogerson \& Visser, 2004; Scheyvens \& Momsen, 2008; Zapata et al., 2011; Duvic et al., 2014; Ramón-Hidalgo et al., 2018; Schmidt \& Uriely, 2018; Yasu et al., 2018). Against such as background, ecotourism development can successfully be achieved at BFRBS only if the locals in the Kubease community continue to be friendly towards the tourists who visit the Sanctuary. For the aforementioned reason, the locals of Kubease were asked to suggest different ways of enhancing their interactions with the tourists. In response, $23.5 \%$ of the respondents said that selling to the visitors would create good interactions between the locals and the tourists. At the time of the current study, during the holidays the Sanctuary received large numbers of visitors, thus providing a venue where the locals could sell their artefacts and food products to the tourists. A small gift shop was available on-site, at which African artworks by some of the community members could be promoted for the tourists to buy on a daily basis. Furthermore $11.9 \%$ of the respondents mentioned that the employment by, and the proper conservation of, the Sanctuary would create additional opportunities for the locals to interact with the tourists. Additionally, $20.5 \%$ of the respondents mentioned that the organising of events and of socialising programmes would increase the interaction between the locals and the tourists (Table 6).

Although the fauna and flora are the primary attractions in the ecotourism business, the organising of such events as festivals, exhibitions and workshops for the stakeholders should ensure good interactions. A copious amount of research posits that festivals can create an opportunity for the exchange of cultures, which is a form of sociocultural benefit, with it also presenting an opportunity for the locals to sell their 
products to the tourists, from which they can receive an alternative income (Eshun, 2011; Manu \& Kuuder, 2012; Mensah \& Adofo, 2013; Eshun, 2014; Eshun \& Tonto, 2014; Eshun \& Tagoe-Darko, 2015). The majority of the respondents (33.3\%) mentioned giving directions and holding face-to-face interactions with the tourists to promote good interactions between themselves and the tourists. Another 5.5\% said that there would be good interaction between the tourists and local, if only the former were allowed to board buses at the lorry station in their community. At the time of the current study, the taxidrivers in the Kubease community benefited greatly from ferrying visitors to the Sanctuary, because the distance from the community to the Sanctuary exceeded $2 \mathrm{~km}$.

Table 6. Factors that will enhance good interactions

between the tourists and the locals (Data source: Fieldwork)

\begin{tabular}{|l|c|}
\hline Response & $\mathbf{n = 3 2 7 , \mathbf { i n } \%}$ \\
\hline Providing avenues for selling to visitors & $\mathbf{2 3 . 5}$ \\
\hline Employment and conservation & 11.9 \\
\hline Organising events and socialising programmes & 20.5 \\
\hline Giving of directions and the conducting of face-to-face interactions & 33.3 \\
\hline Tourists using the buses/taxis provided by the community & 5.5 \\
\hline None & 4.6 \\
\hline Total & 100 \\
\hline
\end{tabular}

Elsewhere, $4.6 \%$ of the respondents said that they had no idea of what would improve the interactions between the tourists and the locals. The uniqueness of tourist destinations encompasses a gamut of such factors as their attractions, activities, amenities, and accessibility (Qu et al., 2011; Yang \& Nair, 2014). Increasingly, tourism developers are realising that the activities at tourism destinations can make tangible an experience in an immutable way (Rogerson \& Visser, 2004; Eshun, 2011; Schmidt \& Uriely, 2018). Based on research undertaken in the Balkans, Duvic et al. (2014, p. 61) state, "it is necessary to connect the culture with the natural resources in order to create complex images, so that visitors could be able to develop an awareness of the community and the local way of life".

Ecotourism development that will enhance the well-being of the locals

The locals are reputed to participate well in ecotourism development, when they have extensive knowledge and skill in the field of Hospitality and Tourism (Buckley, 2009; Eshun, 2011; Zinda et al., 2014). To equip the locals with the required knowledge and skills, training must, therefore, be undertaken in the field concerned (Qu et al., 2011). Consequently, a question was asked, as to "whether training community members in hospitality and tourism will encourage their participation in ecotourism and enhance local well-being". Of the total sample of respondents, the vast majority (98.2\%) responded in the affirmative. In addition, some of the respondents (31.7\%) who did so mentioned that training in Hospitality and Tourism would empower them to take part in the ecotourism development at the BFRBS. Correspondingly, 40.2\% indicated that the knowledge and skills that they gained in Tourism would increase their employability. Also, 21.5\% of the respondents stated that the locals' learning in Tourism and Hospitality would create their awareness of, and their participation in, ecotourism. The remaining $7.5 \%$ added that their training in Tourism and Hospitality would bring about innovations.

Earlier research conducted by Eshun et al. (2015) at the Owabi Wildlife Sanctuary showed that the local residents were inadequately equipped with the requisite marketing and entrepreneurial skills to manage ecotourism ventures, or to exploit their positive externalities. Similarly, at the Mombasa Resort in Kenya, low local involvement and high leakage rates are reported as having significantly reduced the contribution made by tourism to the local socioeconomic development (Akama et al., 2011). A plethora of literature exists 
buttressing the position that, given the right training, the locals can benefit equitably from ecotourism development (Kiss, 2004; Shehab, 2011; Eshun et al., 2016; Yasu et al., 2018). The practice of just informing the local communities on the decisions already taken concerning ecotourism development in Ghana has been shown, at least in part, to shed light on why there is conflict between the local communities and the ecotourism management (Eshun, 2011, 2014). Specifically, some authors have sought to unpack the objectives and the outcomes of local participation on facets of local well-being (Tosun, 2000; Kiss, 2004; Eshun \& Tonto, 2014; Zinda et al., 2014; Eshun et al., 2015; Ramón-Hidalgo et al., 2018).

Furthermore, as many as $315(96.3 \%)$ of the respondents stated clearly that involving them in decision-making was a mechanism whereby they could come to participate in ecotourism, whereas 12 (3.7\%) indicated otherwise. Earlier, Eshun et al. (2014), researching the same ecotourism site, concluded that the locals were aware that involving them in decision-making about the Sanctuary was a mechanism that would help to ensure their participation in ecotourism. Similarly, Boley and McGehee (2014) mounted the argument that the locals participating in ecotourism contribute to their psychological well-being and continued respect for their norms and traditions.

Eshun (2011) showed that, when ecotourism was introduced to Ghana in the 1990s, an overt attempt was made to institute what became known as the Tourism Management Committee (TMC). The TMCs were formed from selected members of the local communities, so as to ensure that community participation took place. However, the research conducted through the years shows that, where the TMCs have come into being, they appear to be superficial mechanisms used by ecotourism management to assume the form of the ensuring of proper local participation (Afenyo, 2012). Such TMCs are also wrought with issues of a lack of transparency and of equitable distribution of the benefits that are generated at the ecotourism sites concerned (Eshun, 2011; Afenyo, 2012; Amoah \& Wiafe, 2012; Eshun, 2014; Eshun \& Tagoe-Darko, 2015). In reality, the TMCs are also poorly trained, especially in tourism management, which, inevitably, reduces the amount of benefits gained from ecotourism by the local communities (Eshun \& Tonto, 2014).

Furthermore, the members of the TMCs tend neither to represent the local population, nor to desire to address the issue of community marginalisation (Eshun, 2011). For example, non-indigenes are often excluded from the benefits to be gained from the Campfire projects conducted in Zimbabwe (Dzingirai, 2003). Similarly, at Makuleke Contract Park in South Africa, the locals, in the past, accused the chief of employing his own family members as part of the Park's staff (Shehab, 2011). Thus, the locals in Kubease were asked to suggest ways in which they could help to ensure their full participation in the associated ecotourism ventures, so as to enhance their sense of well-being. The results show that 84 (25.7\%) of the 327 respondents suggested that giving the locals jobs would do so, whereas $105(32.1 \%)$ indicated that training and education would be required for them to fully participate in the ecotourism involved. The majority of the locals (106; $32.4 \%$ ) also mentioned that the full involvement of the locals in the related decisionmaking would help to ensure a local sense of well-being (Figure 4). Of the locals, 23 (7.0\%) said that recognising the input of the locals would help to ensure local participation in ecotourism development, and some of the respondents $(9 ; 2.8 \%)$ made no suggestion regarding the question. Earlier research that was undertaken into ecotourism development in Ghana concluded that the local people also face the challenge of finding working captital, time and the requisite business acumen to exploit opportunities in the ecotourism trade (Amoah \& Wiafe, 2012). Ultimately, participation in ecotourism towards contributing to the local sense of well-being is likely to remain a naïve chimera, without the adoption of a suitable multipronged approach to ecotourism development, in terms of which the local involvement does not appear to be an activity undertaken on an ad-hoc basis. 


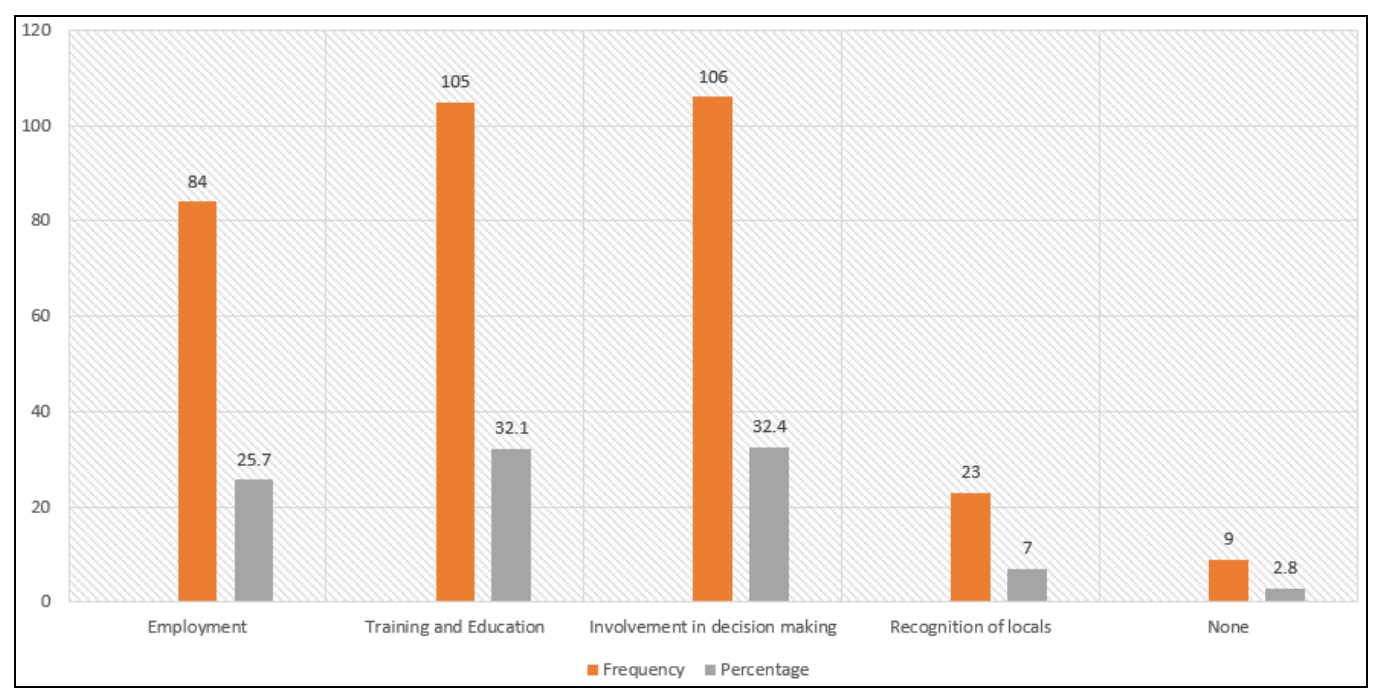

Figure 2. Involvement of the locals in decision-making about the Sanctuary (Source: Fieldwork, 2019)

\section{CONCLUSION}

The current study focused on enhancing the participation in ecotourism development for the promotion of a sense of local well-being. The results showed that the level of local participation in ecotourism at the Sanctuary was low at the time of the research. The locals were little involved in decision-making regarding the Sanctuary. Further, their lack of involvement was also partly due to their lack of knowledge about tourism, as well as to them not having frequent access to the visitors, and as a result of management-imposed restrictions. Currently, at Kubease community, which is the main local community, there is no tangible infrastructure like a market/school/health facility or good roads built due to the benefits that they should have received from the ecotourism conducted in their domain. Many related works posit that such a lack of adequate benefits for the local communities can result in the development of negative attitudes among the locals towards ecotourism development and its sustainability (Kiss, 2004; Lacher \& Nepal, 2010; Eshun, 2011, 2014). The education and training of the locals in the field of Tourism and Hospitality, and employing the locals in such positions as, for example, tour guides could help to empower them to participate fully in ecotourism development at the BFRBS, and it could contribute to the local sense of well-being. Other stakeholders have also to be encouraged by the management of the Sanctuary to play their role in ecotourism, especially in terms of empowering the locals through entrepreneurship.

In the light of the findings of the current study, the following recommendations should be considered to ensure successful local empowerment, so as to enhance the locals' participation in ecotourism development, for their own sense of well-being. The management of the Sanctuary should ensure good and proper engagement between the locals and themselves. The above can be done through ensuring the revival and effectiveness of the TMC, which would help to create cordial relationships between the management and locals, by ensuring that the locals are fully involved in any decisionmaking regarding the Sanctuary. The government, through the Ministry of Tourism, Arts and Culture and the Ghana Tourism Authority, should provide scholarships to some of the residents in the community, so that they can gain professional qualifications and skills in Tourism and Hospitality. The National Tourism and Hospitality Training Policy 2019 provides an avenue for Metropolitan, Municipal and District Assemblies to benefit from such assistance. Such assistance should help to build the local capacity all the way from the 
frontline to the top managers, and it should contribute to Ghana becoming a leading tourism destination in Africa. The overarching challenge has been learning how to sustain engagement with the diverse actors in tourism, so as to ensure local empowerment, product development, and tourism financing, entrepreneurship and marketing. The actors at the Sanctuary must introduce a local festival that will create an avenue for the locals to interact with the visitors, by means of the selling of products and the exhibiting of their culture. Based on the present study's results, the conclusion is drawn that a critical examination of the sense of local well-being must give more space to ecotourism scholarship to ensure that the 'dual mandate' of ecotourism does not continue to remain largely a mirage.

\section{REFERENCES}

Afenyo, E.A., (2012). Community participation in ecotourism, evidence from Tafi Atome, Ghana. African Journal of Hospitality, Tourism and Leisure 2: 1-12.

Akama, J.S., Maingi, S. \& Carmago, B.A., (2011), Wildlife conservation, safari tourism and the role of tourism certification in Kenya: a postcolonial critique, in Tourism Recreation Research, 36 (3), 281-291.

Amoah, M. \& Wiafe, E,D., (2012), Livelihoods of fringe communities and the impacts on the management of conservation area: the case of Kakum National Park in Ghana, International Forestry Review, 14(2), 131-144.

Ashley, C. \& Jones, B., (2001), Joint ventures between communities and tourism investors: experience in Southern Africa, International Journal of Tourism Research, 3(5), 407-423.

Attuquayefio, D. \& Gyampoh, S., (2010), The Boabeng-Fiema Monkey Sanctuary, Ghana: a case for blending traditional and introduced wildlife conservation systems, West African Journal of Applied Ecology, 17, 1-10.

Belsky, J., (1999), Misrepresenting communities: the politics of community-based rural ecotourism in Gales Point Manatee, Belize, Rural Sociology, 64(4), 641-666.

Boley, B., \& McGehee, N., (2014), Measuring empowerment: developing and validating the resident empowerment through Tourism Scale (RETS). Tourism Management. 45, 85- 94.

Brechin, S.R., Wilshusen, P.R., Fortwangler, C.L. \& West, P.C., (2002), Beyond the square wheel: toward a more comprehensive understanding of biodiversity conservation as social and political process, Society and Natural Resource, 15(1), 41-64.

Buckley, R., (2009), Evaluating the net effects of ecotourism on the environment: a framework, first assessment and future research, Journal of Sustainable Tourism, 17(6), 643-672.

Carter, A., Durham, W.H., Driscoll, L. \& Honey, M., (2015), Can ecotourism deliver real economic, social, and environmental benefits? A study of the Osa Peninsula, Costa Rica, Journal of Sustainable Tourism, 23(3), 339-357.

Chan, R. \& Bhatta, K., 2003, Ecotourism planning and sustainable community development: theoretical perspectives for Nepal, South Asian Journal Tourism and Heritage, 6(1), 70-96.

Chuitsi, S., Mukoroverwa, M., Karigambe, P. \& Muzengi, B.K., (2011), The theory and practice of ecotourism in Southern Africa, Journal of Hospitality Management and Tourism, 2(2), 14-21.

Coria, J. \& Calfucura, E., (2012), Ecotourism and the development of indigenous communities: the good, the bad, and the ugly, Ecological Economics, 73, 47-55.

Dumbe, Y., Seebaway, Z.M. \& Eshun, G., (2018), The nexus of traditional ecological knowledge and ecotourism development: a case of Bobiri Forest and Butterfly Sanctuary, Ghana, African Journal of Hospitality, Tourism and Leisure, 7, 1-19.

Duvic, V., Volic, I., Tišma, S. \& Jelinčić, D.A., (2014), Responsible community-based ecotourism initiatives in protected rural areas of the Balkans: case studies from Serbia and Croatia, American Journal of Tourism Management, 3(1), 51-63.

Dzingirai, V., (2003), CAMPFIRE is not for Ndebele migrants: the impact of excluding outsiders from CAMPFIRE in the Zambezi Valley, Zimbabwe, Journal of Southern African Studies, 29(2), 445-459.

Eshetu, A.A., (2014), Development of community-based ecotourism in Borena-Saynt National Park, North-Central Ethiopia: opportunities and challenges, Journal of Hospitality and Tourism Management, 5, 1-12.

Eshun, G., (2011), Ecotourism and social research, VDM, Saarbrücken.

Eshun, G., (2014), Towards the dual mandate of ecotourism in Africa: a comparative study from Ghana, African Insight, 44(3), 164-184.

Eshun, G., Frempong, F., and Adjei, P. O-W, (2014). The Prospects of Ecotourism as a Conservation and Development Tool at Bobiri Butterfly Sanctuary in Ghana. Research on Humanities and Social Science, 4(22):1-9.

Eshun, G., Adjei, P.O.-W. \& Baah, A., (2015), Where is community quality well-being in ecotourism research in Africa? A case from Ghana, African Journal of Hospitality, Tourism and Leisure, 4, 1-12.

Eshun, G., Adjei, P.O.-W. \& Segbefia, A.Y., (2016), Ecotourism and marketing nexus: a study at Bobiri Forest Reserve and Butterfly Sanctuary in Ghana, African Journal of Hospitality, Tourism and Leisure, 5(2), 1-10.

Eshun, G. \& Tagoe-Darko, E., (2015), Ecotourism development in Ghana: a postcolonial analysis, Development of Southern Africa, 32, 392-406. 
Eshun, G. \& Tonto, J.N.P., (2014), Community-based ecotourism: its socio-economic impacts at Boabeng-Fiema Monkey Sanctuary, Ghana. Bulletin of Geography Socio-economic Series, 26, 67-81.

Fennell, D.A., (2014), Ecotourism, Routledge, New York, NY.

Ghana Statistical Service, (2012), Population and housing census, Government of Ghana, Accra.

Harilal, V. \& Tichaawa, T.M., (2018). Ecotourism and Alternative Livelihood Strategies in Cameroon's Protected Areas. EuroEconomica, 37(2), 133-148.

Hellmann, N., (2011), The role of tourism as a strategy for rural community development: evidence from Yunnan Province, China, PhD thesis, Brown University, Providence, RI.

Honey, M., (2008), Ecotourism and sustainable development: who owns paradise? Island Press, Washington, D.C.

Ilies, D.C., Baias, S., Buhas, R., Ilies, A., Herman, G.V., Gaceu, O., Dumbrava, R., Maduta, F., (2017), Environmental education in protected areas. Case study from Bihor County, Romania. GeoJournal of Tourism and Geosites 19(1), 126-132.

Kimbu, A. N. \& Tichaawa, T. M., (2018), Sustainable development goals and Socio-economic development through Tourism in central Africa: myth or reality? GeoJournal of Tourism and Geosites, 23 (3), 780-796.

Kiss, A., (2004), Is community-based ecotourism a good use of biodiversity conservation funds? Trends in Ecology and Evolution, 19(5), 232-237.

Lacher, R.G. \& Nepal, S.K., (2010), From leakages to linkages: local-level strategies for capturing tourism revenue in Northern Thailand, Tourism Geographies, 12(1), 77-99.

Lawson, L.J. \& Weaver, D. B., (2015). Using residents' perceptions research to inform planning and management for sustainable tourism: a study of the Gold Coast Schoolies Week, a contentious tourism event. Journal of Sustainable Tourism, 23(5), 660-682.

Manu, I, \& Kuuder, C-J.W., (2012). Community-based ecotourism and livelihood enhancement in Sirigu, Ghana. International Journal of Humanities and Social Science, 2(18): 97-108.

Mbaiwa, J.E., (2008), Tourism development, rural livelihoods and conservation in the Okavango Delta, Botswana, unpublished PhD thesis, Texas A\&M University, College Station, TX.

Mensah, I. \& Adofo, E., (2013), Community participation in ecotourism: the case of Bobiri Forest Reserve and Butterfly Sanctuary in Ashanti Region of Ghana, American Journal of Tourism Management, 2, 34-42.

Nkemngu, A.-A.P., (2015), Quality of life and tourism impacts: a community perspective, African Journal of Hospitality, Tourism and Leisure, 4(1), 1-12.

Qu, H., Kim, L.H. \& Im, H.H., (2011), A model of destination branding: integrating the concepts of the branding and destination image, Tourism Management, 32, 465-476.

Ramón-Hidalgo, A.-E., Kozak, R.A., Harshaw, H.W. \& Tindall, D.B., (2018), Differential effects of cognitive and structural social capital on empowerment in two community ecotourism projects in Ghana, Society and Natural Resources, 31(1), 57-73.

Rogerson, C.M. \& Visser, G., (2004), Tourism and development issues in contemporary South Africa, Africa Institute of South Africa, Pretoria.

Scheyvens, R. \& Momsen, J.H., (2008), Tourism and poverty reduction: issues for small island states, Tourism Geographies, 10(1), 22-41.

Schmidt, J. \& Uriely, N., (2018), Tourism development and the empowerment of local communities: the case of Mitzpe Ramon, a peripheral town in the Israeli Negev Desert, Journal of Sustainable Tourism, 1-21.

Shehab, M., (2011), Tourism-led development in South Africa: a case study of Makuleke partnership with Wilderness Safaris, PhD thesis, University of Witwatersrand, Johannesburg.

Simpson, M.C., (2008), Community benefit tourism initiatives-A conceptual oxymoron? Tourism Management, $29(1), 1-18$.

Tichaawa, T.M. \& Mhlanga, O., (2015), Community perceptions of a community-based tourism project: a case study of the CAMPFIRE programme in Zimbabwe, African Journal for Physical Health Education, Recreation and Dance, Supplement 1 (December), 55-67.

Tosun, C., (2000), Limits to community participation in the tourism development process in developing countries, Tourism Management, 21(6), 613-633.

Wagner, M.R., Cobbinah, J.R. \& Bosu, P.P., (2008), Forest entomology in West Tropical Africa: forest insects of Ghana, 2nd edition, Springer, Dordrecht.

Yang, C.L. \& Nair, V., (2014), Risk perception study in tourism: are we really measuring perceived risk?, Procedia - Social and Behavioral Sciences, 144, 322-327.

Yasu, C.M., Baños, M.R. \& Hazael, C.M., (2018), Ecotourism as a path to sustainable development in an isolated Magic Town: the case study of La Trampa, Mexico, Journal of Tourism Analysis, 25(1), 23-38.

Zapata, M.J., Hall, C.M., Lindo, P. \& Vanderschaeghe, M., (2011), Can community-based tourism contribute to development and poverty alleviation? Lessons from Nicaragua, Current Issues in Tourism, 14(8), 725-749.

Zinda, J.A., Yang, J., Xue, X. \& Cheng, H., (2014), Varying impacts of tourism participation on natural resource use in communities in Southwest China, Human Ecology, 42(5), 739-751.

*** The International Ecotourism Society, (2005), The TIES global ecotourism fact sheet, www.ecotourism.org /atf/cf, accessed 25 August 2019.

*** World Travel and Tourism Council (WTTC). (2019). Travel and tourism economic impact 2017, South Africa, WTTC, London.

Submitted:

18.07.2019
Revised:

04.12.2019
Accepted and published online 06.12.2019 